\title{
Kjøp av tobakk blant mindreårige
}

\begin{abstract}
Sammendrag
Bakgrunn. En tidligere norsk studie viste at mindreårige røykere oftest selv kjøper sine sigaretter. Legeforeningen har nylig foreslått å heve aldersgrensen for kjøp av tobakk til 20 år. Her presenteres nye data om hvor mange mindreårige som selv kjøper sigaretter og snus, samt kjennetegn ved de mindreårige røykere og snusbrukere som selv kjøper tobakk.
\end{abstract}

Materiale og metode. I alt 17253 elever i alderen 13-17 år deltok i en skoleundersøkelse i 2004. De besvarte spørsmål om tobakksbruk og i hvilken grad de selv kjøpte sigaretter og snus.

Resultater. $40 \%$ av røykerne og $45 \%$ av snusbrukerne oppga at de som oftest selv kjøpte tobakken. De som røykte eller brukte snus daglig, var mest tilbøyelige til å kjøpe tobakk selv. Om lag $60 \%$ av sigarettforbruket og om lag $70 \%$ av snusforbruket hadde de mindreårige selv kjøpt. Sannsynligheten for at de mindreårige tobakksbrukerne selv kjøpte sigaretter eller snus, $ø$ kte med alder og var høyere blant gutter, blant ungdom som så eldre ut enn jevnaldrende og ungdom som hadde brukt falsk legitimasjon.

Fortolkning. Mindreåriges eget kjøp av tobakk synes å være like utbredt som ved forrige undersøkelse av dette. Myndighetene bør vurdere virkemidler for å bedre håndhevelsen av aldersgrensen.

\author{
Ingeborg Rossow \\ ir@sirus.no \\ Statens institutt for rusmiddelforskning \\ $\emptyset$ vre Slottsgate 2b \\ 0105 Oslo

\section{Willy Pedersen} \\ Institutt for sosiologi og samfunnsgeografi, \\ Universitetet i Oslo \\ Statens institutt for rusmiddelforskning

\section{Karl Erik Lund} \\ Statens institutt for rusmiddelforskning
}

Sigarettrøyking er en av de viktigste risikofaktorene for tapte friske leveår i Vest-Europa (1), og et viktig mål for helsefremmende arbeid er å begrense røyking i befolkningen. Lav alder for røykestart er knyttet til høy nikotinavhengighet (2). Derfor har myndighetenes tobakksforebyggende strategiplaner vektlagt forebyggende tiltak overfor barn og unge, deriblant aldersgrensebestemmelser for kjøp av tobakk (3). I Norge ble aldersgrensen satt til 16 år i 1975 og hevet til 18 år i 1996. Omfanget av dagligrøyking blant tenåringer er likevel betydelig. I 2004 var andelen $10 \%$ blant 16 -åringer og $15 \%$ blant 17-åringer (4). I tillegg røykte henholdsvis $5 \%$ og $13 \%$ av og til.

Mindreåriges tilgang på tobakk fra kommersielle kilder som butikker og kiosker er i økende grad tematisert i det tobakksforebyggende arbeidet i Norge. Helsedirektoratets forslag om et bøte- og bevillingssystem for salg av tobakk var i sin tid begrunnet $i$ dette hensynet. Nylig foreslo Legeforeningen å heve aldersgrensen for kjøp av tobakk til 20 år for å gjøre det vanskeligere for tenåringer å kjøpe tobakk.

En studie av 13-17 år gamle røykere viste at $52 \%$ vanligvis kjøpte sigarettene selv (5), $70 \%$ rapporterte at de aldri ble spurt om alderen når de forsøkte å kjøpe tobakk, og bare $48 \%$ hadde noen gang opplevd å bli nektet kjøp (5). Resultatet førte til at helseministeren ba forhandlernes organisasjoner bedre håndhevingen av aldersgrensebestemmelsen. Etter to års virksomhet med forhandlerinformasjon ble undersøkelsen om ungdoms forsyningskilder gjentatt. Til tross for at tenåringene denne gang rapporterte om noe høyere opplevd kjøpskontroll, var graden av selvforsyning den samme (6).

I løpet av de siste ti årene har andelen unge som bruker snus, økt (7). De helsemessige konsekvensene av snusbruk er mindre enn for tobakksrøyking (8), men ikke ubetydelige, og en 18-års aldersgrense også for kjøp av snus reflekterer målsettingen om å begrense initiering og bruk av snus i yngre aldersgrupper (3).

Hensikten med denne studien var å tilføre oppdatert kunnskap om omfanget av mindreåriges eget kjøp av tobakk. I tillegg ønsket vi å identifisere kjennetegn ved mindreårige røykere og snusbrukere som selv får kjøpt tobakk.

\section{Materiale og metode}

Studien er basert på data fra en stor spørreundersøkelse blant norske ungdommer fra 2004 (9). Alle elever i ungdomsskole og videregående skole (totalt 91 skoler) i 16 norske kommuner ble invitert til å delta. Kommunene representerte alle landsdeler og så vel byer som landdistrikter. Elever under 18 år måtte ha informert samtykke fra foresatte. I alt $80,2 \%$ av elevene i bruttoutvalget deltok, og nettoutvalget omfattet vel 20700 elever. Av disse var 17253 under 18 år, og kjønns- og aldersfordelingen var jevn. Undersøkelsen ble godkjent av Norsk samfunnsvitenskapelig datatjeneste. De metodiske detaljene omkring spørreundersøkelsen er publisert $\mathrm{i}$ en egen metoderapport (10).

Elevene fylte ut et spørreskjema i løpet av en skoletime. Vi spurte blant annet: «Røyker du sigaretter?» og «Bruker du snus?»- begge med svaralternativene «Nei», «Ja, men ikke daglig» og «Ja, daglig». De som svarte bekreftende, ble bedt om å angi hvor mange sigaretter de røykte per dag (åpent spørsmål) og hvor mange bokser med snus de brukte per uke (åpent spørsmål). Svarene ble trunkert ved 40 for sigaretter per dag og 15 for snusbokser per uke. Elevene ble spurt om de selv kjøpte sigaretter/snus i butikk, i kiosk, på bensinstasjon eller liknende med følgende svaralternativer: «Alltid», «Som regel», «Av og til» og «Aldri». Et tilnærmet mål på hvor mange sigaretter/snusbokser som ungdommene hadde kjøpt selv, ble beregnet ved å multiplisere antall røykte sigaretter per

\section{Hovedbudskap}

- Fremdeles kjøper mindreårige røykere oftest sigarettene sine selv

- Det samme gjelder mindreårige snusbrukere 
dag/antall snusbokser per uke: med 1,0 for dem som alltid kjøpte selv, med 0,8 for dem som oppga at de som regel kjøpte selv, med 0,2 for dem som av og til kjøpte selv, og med 0 for dem som aldri kjøpte selv. Vi har også gjort de samme beregningene med litt høyere faktorer for dem som kjøpte selv «som regel» og «av og til» $(0,9$ og 0,3$)$ og med lavere faktor for dem som kjøpte selv «som regel» $(0,7)$.

Andelen sigaretter som ble skaffet på denne måten, ble beregnet ved å dividere det beregnede antall røykte sigaretter som de hadde kjøpt selv, med det totale antall røykte sigaretter. Tilsvarende beregninger ble gjort for andelen snusbokser. Forklaringsvariabler som inngår i analysene er kjønn, alder, hvorvidt de hadde brukt falsk legitimasjon (i butikk, på kino, utested, etc.) i løpet av siste år og elevenes egen vurdering av om de så eldre ut enn sine jevnaldrende. Sistnevnte var dikotomisert fra en opprinnelig variabel med sju svarkategorier fra «Mye eldre» til «Mye yngre».

\section{Statistiske analyser}

Bivariate sammenhenger av kategoriske variabler er analysert med krysstabeller og khikvadrattest samt i bivariate logistiske regresjonsmodeller for beregning av ujustert oddsratio. Sannsynlighet for at respondentene alltid eller som regel hadde fått kjøpt sigaretter eller snus i butikk eller liknende, ble analysert i multivariate logistiske regresjonsmodeller. Forklaringsvariablene - kjønn, alder, daglig røyking/daglig snusbruk, om man så eldre ut enn sin egen alder, og bruk av falsk legitimasjon siste år - ble inkludert trinnvis på grunnlag av modelltilpasningskriterier (log likelihood ratio). Tilsvarende ble andelen sigaretter eller snusbokser som respondentene selv hadde kjøpt, analysert i multivariate lineære regresjonsmodeller hvor forklaringsvariablene ble inkludert trinnvis på grunnlag av modelltilpasning. På grunn av stort utvalg ble terskelverdien for variabelinklusjon satt til $\mathrm{p}<0,01 \mathrm{i}$ alle multivariate analyser. Analysene er gjort i SPSS 17.0.

\section{Resultater}

Blant de vel 17000 respondentene under 18 år var det 2598 røykere; 1424 (8,3\%) dagligrøykere og 1174 (6,8\%) av-og-til-røykere. Det var $596(3,5 \%)$ som svarte at de brukte snus daglig og $1274(7,4 \%)$ som brukte snus av og til, dvs. i alt 1870 snusbrukere. Andelen røykere var noe høyere blant jenter ( $9,4 \%$ daglig og $8,4 \%$ av og til) enn blant gutter (7,0\% daglig og 5,2\% av og til), mens snusbruk var klart mer utbredt blant gutter $(6,5 \%$ daglig og $11,0 \%$ av og til) enn blant jenter $(0,5 \%$ daglig og 3,9\% av og til). Både røyking og snusbruk var mer utbredt med økende alder. Andelen dagligrøykere var $1 \%$ blant 13-åringene og $17 \%$ blant 17-åringene, mens de tilsvarende andelene som brukte snus daglig, var henholdsvis $0,4 \%$ og $7 \%$. Nesten halvparten $(45 \%)$ av dem som brukte snus daglig eller av og til, oppga at de også røykte, og en tredel $(32 \%)$ av dem som røykte daglig eller av og til, oppga at de også brukte snus. Blant røykerne var det $40 \%$ som oppga at de alltid eller som regel kjøpte sigaretter selv. Denne andelen var høyere blant dagligrøykere enn av-og-til-røykere, høyere blant gutter enn blant jenter, høyere i den eldste aldersgruppen, høyere blant dem som så eldre ut for sin alder og høyere blant dem som hadde brukt falsk legitimasjon (tab 1). Blant snusbrukerne var det $45 \%$ som oppga at de alltid eller som regel kjøpte snus selv, og variasjonsmønsteret for denne andelen avtegnet det samme bildet som for andelen som hadde kjøpt sigaretter selv (tab 1).

De mindreårige røykerne oppga et gjennomsnittlig sigarettforbruk på vel 6,4 sigaretter per dag. Av dette har vi beregnet at $58 \%$ var selvkjøp. Tilsvarende oppga de mindreårige snusbrukerne et gjennomsnittlig forbruk på 1,29 snusbokser per uke hvorav $68 \%$ var selvkjøp. Den beregnede andelen av sigaretter og snus som de selv hadde kjøpt, ble ikke vesensforskjellig når vi endret beregningsforutsetningene som beskrevet $\mathrm{i}$ metodedelen: for sigaretter varierte andelen da mellom $54 \%$ og $64 \%$ og for snus mellom $65 \%$ og $73 \%$.

Multivariate logistiske regresjonsanalyser viste at sannsynligheten for selv å kjøpe sigaretter/snus alltid eller som regel var 2,5-3 ganger høyere for gutter enn for jenter (tab 2). Den var 30-40\% høyere blant 16-17-åringene enn blant 13-15-åringene, den var om lag 3-4 ganger høyere for daglige røykere/snusere $\mathrm{i}$ forhold til av-og-tilrøykere/snusere, den var høyere for dem som så eldre ut enn sine jevnaldrende, og den var høyere blant dem som hadde brukt falsk legitimasjon. Mønsteret var det samme for sigaretter og snus. På samme måte har vi også analysert variasjonen $\mathrm{i}$ andelen av sigaretter og snus som respondentene selv hadde kjøpt. Multivariate lineære regresjonsmodeller viste samme mønster her.

\section{Diskusjon}

Studien viser at hele $40-45 \%$ av tobakksbrukerne under 18 år som oftest selv kjøper sigaretter eller snus. De som røykte eller brukte snus daglig, var mest tilbøyelige til å gjøre det, og beregningene tyder på at de mindreårige har skaffet seg størstedelen av forbruket av sigaretter ved eget kjøp. Dette er i tråd med hva som tidligere har vært rapportert med hensyn til mindreåriges sigarettkonsum i Norge $(5,6)$. Nytt i denne studien er at det samme gjelder mindreåriges bruk av snus. Vi fant at ungdom som begynte å nærme seg aldersgrensen, hadde større sannsynlighet for å kjøpe tobakken selv, og tilsvarende er også rapportert fra flere tidligere studier (11). Det samme gjaldt dem som røykte eller brukte snus daglig, samt dem som så voksne ut for alderen. Andelen som kjøpte tobakken selv, var også høyere blant dem som hadde brukt falsk legitimasjon. Likevel hadde flertallet av dem som selv alltid eller som regel kjøpte tobakk, ikke brukt falsk legitimasjon i det hele tatt siste år.

Studien bygger på et uvanlig stort datamateriale. Utvalg og responsrate skulle tilsi en god representativitet av 13-17-åringer i Norge, og det store utvalget har gjort det 
Tabell 2 Sannsynlighet for at røykere/snusbrukere alltid eller som regel selv har kjøpt henholdsvis sigaretter/snus i butikk, kiosk, bensinstasjon eller liknende etter kjønn, alder, tobakks bruk, utseende for alder og bruk av falsk legitimasjon. Ujusterte og justerte oddsratioer (med $95 \%$ konfidensintervall i parentes)

Selv kjøpt sigaretter ( $\mathrm{n}=2$ 497) Ujustert Justert OR $2,5(2,2-3,0)$ $1,3(1,2-1,4)$ $\mathrm{OR}$

\section{Kjønn}

Alder $3,2(2,7-3,8)$ $1,2(1,1-1,3)$

Daglig røyk/snus

Ser eldre ut enn jevnaldrende $2,2(1,8-2,5)$ $3,0(2,5-3,6)$

$$
2,4(2,0-2,9)
$$

sjon siste år $2,6(2,2-3,2)$

Selv kjøpt snus ( $\mathrm{n}=1810$ ) Ujustert Justert OR

$3,9(3,0-5,1)$

$3,2(2,4-4,2)$

$1,4(1,2-1,5)$

$1,3(1,3-1,5)$

$4,4(3,6-5,5)$ $3,8(3,1-4,8)$ $1,8(1,4-2,1)$ $1,9(1,5-2,3)$

Referansekategorier for forklaringsvariabler:

Kjønn (jente), alder (13-15 år), tobakksbruk (av og til), ser eldre ut enn jevnaldrende (nei), brukt falsk legitimasjon siste år (nei).

Alle sammenhenger er statistisk signifikante $p<0,001$

mulig å belyse hvordan selvforsyning av tobakk er knyttet til en rekke faktorer. Studien er også den første i Norge som har belyst selvforsyning av snus blant mindreårige. Målene på tilgjengelighet av tobakk var ikke særlig detaljerte. Under- eller overrapportering av tobakksbruk og selvforsyning av tobakk vil ha betydning for nivå og sammenhenger $\mathrm{i}$ observasjonene fra studien. Vi vet ikke hvordan ungdommene skaffet seg tobakk når de ikke selv kjøpte i butikk. Det er mulig at alternative kilder er som for alkohol (12): fått eller kjøpt av andre ungdommer, fått voksne til å kjøpe for seg eller fått eller stjålet hjemme. Dersom en del mindreårige også kjøper tobakk i butikk til andre mindreårige, vil det innebære at en større andel av tobakksbruken blant disse unge blir kjøpt i butikk enn hva våre beregninger har vist. Man kunne også ha ønsket seg mål på hvorvidt eller hvor ofte mindreårige tobakksbrukere ble bedt om å vise legitimasjon eller ble nektet kjøp.

Studier fra andre land - blant annet USA (13) - har vist at det meste av mindreåriges tobakksforbruk fremskaffes gjennom eget kjøp, og at slik selvforsyning er høyest $i$ områder med høy andel røykere og med svake sosioøkonomiske ressurser (10).

Funnene våre impliserer at bedre begrensning av mindreåriges tilgang til sigaretter og snus kan tenkes å være en viktig forbyggingsstrategi overfor ungdom. Tidligere forskning peker i retning av at aldersgrenser kan være et viktig tiltak på dette feltet, men at det forutsetter skikkelig håndhevelse (14, 15). Butikkansatte har få incentiv for å håndheve aldersgrensen for kjøp av tobakk. Det kan også være vanskelig for dem å vurdere ungdoms alder, og noen mindreårige bruker falsk legitimasjon. Våre funn peker imidlertid i retning av at dette i så fall bare kan forklare en begrenset del av tobakkssalget til mindreårige; flertallet av dem som hadde kjøpt tobakk selv, hadde ikke brukt falsk legitimasjon i det hele tatt.
En litteraturgjennomgang (6) viste at bevilling for salg av tobakk synes å være et hensiktsmessig og effektivt virkemiddel for å redusere tilgjengelighet og bruk av tobakk blant mindreårig ungdom, mens henstillinger til forhandlerne om å etterkomme aldersgrensen for salg av tobakk ikke har hatt ønsket effekt, verken i Norge eller i andre land. Lisensiering av forhandlere - med fare for tap av bevilling ved salg av tobakk til mindreårige - er det virkemidlet for å overholde aldersgrensen som har ført til nedgang i selvforsyning blant barn og unge. Andre røykeforebyggende tiltak overfor ungdom som undervisningsprogrammer - vil kunne få bedre effekt dersom aldersgrensen håndheves bedre (6). Hvis norske myndigheter iverksetter tiltak som lisensiering av forhandlere og/eller heving av aldersgrensen for å begrense ungdoms tilgang til og bruk av tobakk, bør dette selvsagt bli forskningsmessig evaluert.

\section{Konklusjon}

Mindreårige tobakksbrukere er fremdeles i stor grad selvforsynt med både sigaretter og snus. Blant tobakksbrukere er det særlig dem som røyker eller snuser daglig, gutter og eldre tenåringer som i større grad er selvforsynt med sigaretter og snus.

Arbeidet med denne artikkelen er finansiert av Statens institutt for rusmiddelforskning

\section{Oppgitte interessekonflikter: Ingen}

\section{Litteratur}

1. Lopez AD, Mathers CD, Ezzati M et al. Global burden of disease and risk factors 2006. Washing ton, D.C., 2006.

2. Kraft $P$, Svendsen $T$, Hauknes A. Intention to stop smoking among Norwegian smokers: The role of nicotine dependence, type of cigarettes, and age of onset of daily smoking Addict Behav 1998; 23: $133-7$.

3. Nasjonal strategiplan for det tobakksforebyggende arbeidet 2006-2010.2006. Oslo: Helse og omsorgsdepartementet, 2006.
4. Wiium N, Aarø LE, Hetland J Subjective attractiveness and perceived trendiness in smoking and snus use: a study among young Norwegians. Health Educ Res 2008; 24: $162-72$

5. Lund KE, Urdal L, Sanner T. Hvordan håndheves 18-årsgrensen for kjøp av tobakk? Tidsskr Nor Lægeforen 1999; 119: 3753-5.

6. Lund KE, Rise J. En gjennomgang av forskningslitteraturen om tiltak for å redusere røyking blant ungdom.2002. Oslo: Sosial- og helsedirektoratet, 2002

7. Øverland S, Hetland J, Aarø LE. Røyking og snusbruk blant ungdommar i 2004 og 2007. Tidsskr Norske Legeforen 2008; 128: 1820-4.

8. SCENIHR (Scientific committee on emerging and newly identified health risks). Health effects of smokeless tobacco products 2008. Brussel: European Commision, 2008.

9. Pape H, Rossow I, Storvoll EE. Metoderapport for Skoleundersøkelsene 2004, 2005 og 2006 i tilknytning til SIRUS' evaluering av Regionprosjektet. 2007. Oslo: Statens institutt for rusmiddelforskning, 2007.

10. Lipton R, Banerjee A, Levy D et al. The spatial distribution of underage tobacco sales in Los Angeles. Subst Use Misuse 2008; 43: 1594-614.

11. Clark PI, Natanblut SL, Schmitt CL et al. Factors associated with tobacco sales to minors: lessons learned from the FDA compliance checks. JAMA 2000; 284: 729-34.

12. Rossow I, Pape H. Storvoll EE. Beruselsens kilder - hvordan ungdom skaffer seg alkohol. Tidsskr Nor Lægeforen 2005: 125: 1160-2.

13. Forster JL, Wolfson M. Youth access to tobacco: policies and politics. Annu Rev Public Health 1998 19: $203-35$.

14. Hagquist C. Sundh M, Eriksson C. Smoking habits before and after the introduction of a minimumage law for tobacco purchase: Analysis of data on adolescents from three regions of Sweden. Scand J Public Health 2007; 35: 372-9.

15. Tutt DC. Enforcing law on tobacco sales to minors: getting the question and action right. NSW Public Health Bulletin 2008; 19: 208-11

Manuskriptet ble mottatt 15.4. 2009 og godkjent 11.3. 2010. Medisinsk redaktør Are Brean. 